\title{
Speciation of antimony (III) and antimony (V) using hydride generation for meglumine antimoniate pharmaceutical formulations quality control
}

\author{
Lúcio Mendes Cabral/1/+, Vânia Neves Moreira Juliano, Luiza Rosario Sousa Dias ${ }^{2}$, \\ Camila Braga Dornelas', Carlos Rangel Rodrigues ${ }^{3}$, Michele Villardi', Helena Carla Castro ${ }^{4}$, \\ Tereza Cristina dos Santos/ ${ }^{5}$
}

\begin{abstract}
Departamento de Medicamentos, Instituto Nacional de Controle de Qualidade em Saúde-Fiocruz, ${ }^{5}$ Instituto de Tecnologia de FármacosFiocruz, Av. Brasil 4365, 21045-900 Rio de Janeiro, RJ, Brasil 'Laboratório de Tecnologia Industrial Farmacêutica, Departamento de Tecnologia Farmacêutica ${ }^{3}$ Laboratório de Modelagem Molecular e QSAR, Departamento de Biologia Celular e Molecular, Faculdade de Farmácia, Universidade Federal do Rio de Janeiro, RJ, Brasil 'Laboratório de Química Medicinal, Departamento de Medicamentos, Faculdade de Farmácia ${ }^{4}$ Laboratório de Biologia Molecular, Instituto de Biologia, Universidade Federal Fluminense, Niterói, RJ, Brasil
\end{abstract}

The pentavalent antimonies, mainly the meglumine antimoniate, are recommends as first-choice medicines for leishmaniasis therapy. In this work we described the development of formulations of meglumine antimoniate injectable medication, as well as the analytical methodology used in the selective determination of Sb(III) and Sb(Total) by hydride generation - inductively coupled plasma atomic emission spectrometry (HG-ICP-AES) and ICP-AES, respectively. On that purpose the analytical methodology was developed focusing on the HG-ICP-AES technique. The formulations using propylene glycol/water as vehicles in a 20:80 proportion were more appropriate for subsequent use in industrial scale. These formulations also showed a lower variation on Sb(III) percentage, no need of buffer solution to stabilize the formulation and no influence of the autoclaving in the quality of the product. The results of the development of the analytical methodology point out the proposed method as an efficient alternative for the determination of $S b(I I I)$ in the presence of large quantities of $S b(V)$ in injectable solutions of meglumine antimoniate, in a selective, linear, accurate and precise manner. In addition, the method showed a low limit of quantification, less interference of the matrix, and more resilience than batch techniques proposed in the Brazilian Pharmacopeia.

Key words: antimony - stibine - hydride generation - inductively coupled plasma atomic emission spectrometry - formulation analysis - stabilization

Among the different therapeutic alternatives available for leishmaniasis therapy, World Health Organization recommends as first-choice medicines the pentavalent antimonies, mainly the meglumine antimoniate (Croft 1988, WHO 2007). Although the mechanism of the pentavalent antimonies is not fully elucidated, many studies have suggested that its therapeutic profile is due to their conversion in the trivalent form inside the infected macrophages (Berman \& Wyler 1980, Callahan et al. 1997, Ephros et al. 1997, WHO 2007). The antimonial compounds are parenterally administered as they irritate the intestinal mucosa, and present a low absorption rate in the gastrointestinal tract (Pintado \& Lopez-Velez 2001). They are obtained from the reaction between the antimony oxide (V) $\left(\mathrm{Sb}_{2} \mathrm{O}_{5}\right)$ and $\mathrm{N}$-methylglucamine, and their chemical structure was not fully determined. Studies on the structural characterization of these drugs show that they are a mixture of oligomers with different molecular weights. Each antimony atom may be connected in a coordinated manner through two hydroxyl groups of the adjacent moiety of the N-methylglucamine, being easily

Financial support: FAPERJ, UFF, CNPq

+Corresponding author:1mcabral@pharma.ufrj.br

Received 26 July 2007

Accepted 20 March 2008 hydrolyzed by diluted acids with the release of the $\mathrm{Sb}$ (V) (Roberts et al. 1998). Thus, the $\mathrm{pH}$ is important to the formulation stability and to the therapeutic profile (Carrió et al. 2000). The oxidized form of antimonies is unstable and molecular modifications may occur. The most dangerous of these modifications is the reduction to $\mathrm{Sb}(\mathrm{III})$, which constitutes a highly toxic chemical species (Marsden 1979, Balana-Fouce et al. 1998, Feng et al. 1999, WHO 2007). The presence of Sb(III) outside the parasite organism may be responsible for the variability of the response to treatment with antimonial compounds. Studies using different medication samples containing this drug detected considerable percentages of $\mathrm{Sb}(\mathrm{III})$ (Sundar et al. 1998). It suggests that the stabilization of the drug is undermined for maintaining the $\mathrm{Sb}(\mathrm{V})$.

There are several methods to separate simultaneously and quantify the species $\mathrm{Sb}(\mathrm{III})$ and $\mathrm{Sb}(\mathrm{V})$ in the pharmaceutical formulations such as: capillary electrophoresis -inductively coupled plasma mass spectrometry (CE-ICPMS) (Michalke \& Schramel 1999); high performance liquid chromatography hydride generation-atomic fluorescence spectrometry detection (HPLC-HG-AFS) (Apte \& Howard 1986, Casiot et al. 1998, Cava-Montesinos et al. 2003, González et al. 2005, Morita et al. 2007); spectrophotometric methods with flow injection (Bloomfield et al. 1992, Rath et al. 1997, Trivelin et al. 2006); high performance liquid chromatography-hydride generation-atomic absorption spectrometry detection (HPLC- 
HG-AAS) (Smichowski et al. 1995, Lintschinger et al. 1997, Zhang et al. 1998, Lindemann et al. 1999, Zheng et al. 2000); and ICP-MS (Lintschinger et al. 1998, Ulrich 1998a, b, Zheng et al. 2001). Even though these methods are the most appropriate for speciation of antimony, they are poorly suitable for the employment in the routine of medication quality control, which demands simple and more affordable methods. Literature reported some reports such as those of Andreae and co-workers that described the determination of $\mathrm{Sb}$ species in meglumine antimoniate solutions in other different matrix (Andreas et al. 1981). Excellent results were obtained with the HG-AAS, which consists of reducing $\mathrm{Sb}(\mathrm{V})$ to $\mathrm{Sb}(\mathrm{III})$ in the diluted meglumine antimoniate solution, as $\mathrm{Sb}(\mathrm{V})$ presents low reactivity to generate stibine with tetrahydroborate. Flores and co-workers determined $\mathrm{Sb}$ (III) and total antimony in an injectable pharmaceutical formulation using a flow injection hydride generation atomic absorption spectrometry (Flores et al. 2002, 2003). The method is based in the selective complexation of the species of antimony, to allow, under optimum analysis conditions, the formation of stibine from the trivalent species without the interference of $\mathrm{Sb}(\mathrm{V})$, even if it is present in large concentrations. The Brazilian Pharmacopeia (official compendium) recommends analysis by HG-AAS with batch system (Brazilian Pharmacopeia 2002). However, the hybride generation- atomic emission spectrometry (HG-AES) in continuous flow is more appropriate as it eliminates the chemical interference in the gaseous phase found in AAS, reducing the matrix effect. It is also more efficient as it enables the automated analysis. Flow systems are preferable to batch systems due to the continuous stabilization of the bottom generated by the products $\left(\mathrm{H}_{2}\right.$ and $\left.\mathrm{H}_{2} \mathrm{O}\right)$. In fact they are produced in a constant flow in the first system different from the second system (Barra et al. 2000).

Considering the need for establishing minimal quality parameters for the medications globally used in leishmaniasis therapy, and lack of interest of the pharmaceutical industry in producing this type of drugs, our purpose was to develop an injectable formulation that stabilizes the oxidized form of antimony. This work also focused on the development and validation of an analytical methodology capable of determining not only the concentration of generated $\mathrm{Sb}$ (III) but also the stability of the product, to fulfill the information gap present in the current scientific literature and in the Brazilian Pharmacopeia (2002).

\section{MATERIALS AND METHODS}

Apparatus - A sequential ICP-AES, model ULTIMA-2 (JOBIN YVON), attached to an automatic sampler (JOBIN YVON AS 421) was used. A peristaltic pump (MINIPULS 3 GILSON $^{\circledR}$ ) was used to insert the citric acid and sodium borohydride $\left(\mathrm{NaBH}_{4}\right)$ solutions, and another peristaltic pump (LAB CRAFT MOD. HYDRIS 05) to drain the liquid in the liquid-gas separation chamber for disposal. Both peristaltic pumps were connected to the liquid-gas separation chamber, used for $\mathrm{HG}$ through Tygon tubes. Background correction was made by subtracting the off-peak spectral background.
The apparatus used also included the analytical scale precision (0.0001) (GEHAKA AG 200); doubledoor horizontal autoclave $\left(\mathrm{SERCOM}^{\circledR}\right)$ and the product packaging machine (Martinez Taboada ${ }^{\circledR}$ ), qualified and calibrated according to the current rules of Good Manufacture Practices; climate chamber (MS-MISTURA ${ }^{\circledR}$ ) model MSM 013/RS, calibrated and qualified according to the ISO 17,025 guidelines, used for the accelerated study of product ampoule stability. The sterilizing filtration was conducted in $0.22 \mu \mathrm{m}$ (Millipore ${ }^{\circledR}$ ) cartridges, with a 316 stainless steel hull.

Chemicals and reagents - The materials used in the preparation of the formulations were of pharmaceutical grade: N-methyl glucamine antimoniate from Aventis Pharma Romainville-France; Sodium metabisulfite from Basf - Brazil; Disodium ethylenediamine tetraacetate from Farmos - Brazil; Methylparaben (nipagim) USP Proquímica - Brazil; Sodium Hydroxide from Merck; Potassium phosphate monobasic from Vetec - Brazil; Propylene glycol from Dow Química S.A. - Brazil. WFI water used in the preparation of the formulations was previously evaluated regarding the presence of heavy metals and antimony by atomic absorption. All reagents used to prepare the analytical solutions and samples were of analytical grade. Milli-Q water $(>16 \mathrm{M} \Omega$ ) was used in all analytical procedures. The type I ampoules for product packaging were provided by Shott glass, recommended for packaging of injectables by USP. The inorganic standards of $\mathrm{Sb}(\mathrm{III})\left(\mathrm{K}(\mathrm{SbO}) \mathrm{C}_{4} \mathrm{H}_{4} \mathrm{O}_{6}+0,5 \mathrm{H}_{2} \mathrm{O}\right)$ were obtained from Merck titrisol ${ }^{\mathbb{R}}$, and that for $\mathrm{Sb}(\mathrm{V})$ $-\mathrm{KSb}(\mathrm{OH})_{6}$ - was obtained from Sigma-Aldrich. In addition, the meglumine antimoniate ampoules used to optimize and validate the analytical method were obtained from the Aventis Pharma-Brazil Laboratory. The analytical solutions were prepared from $\mathrm{Sb}(\mathrm{V})$ and $\mathrm{Sb}(\mathrm{III})$ stock solution $(1,000 \mathrm{ppm})$ in water. The reducing agent in the $\mathrm{Sb}$ (III) determination and the complexation agent were $\mathrm{NaBH}_{4} 2 \%$ solution, stabilized with $\mathrm{NaOH} 0,01 \mathrm{~mol} / \mathrm{l}$, and a freshly prepared citric acid $30 \%$ solution. In order to determine the $\mathrm{Sb}$ (Total) amount, the solutions were diluted in tartaric acid $0.5 \%$ (Merck) prepared at the moment of analysis. The blank samples were prepared in the same way of analytical samples without antimony.

Procedures - Hydride generation - inductively coupled plasma optical emission spectrometry (HG-ICPOES) and ICP-OES were used to determine the $\mathrm{Sb}(\mathrm{III})$ and $\mathrm{Sb}$ (Total) amounts, respectively, in the formulations of meglumine antimoniate injectable solutions. The $\mathrm{Sb}(\mathrm{V})$ percentage in samples was determined by subtracting the $\mathrm{Sb}$ (III) amount from the $\mathrm{Sb}$ (Total) amount. The ICP-OES technique is based on measurement of light emission from excited atoms and ions. The excitation occurs in argon plasma at a temperature up to $10,000 \mathrm{~K}$. The intensity of luminous radiation emitted in a 206,833 $\mathrm{nm}$ wavelength allowed the quantification of $\mathrm{Sb}$ (Total). We selected the wavelength by analyzing the free lines of spectral interference for the Sb. For the nebulization of the sample, a Mira-Mist nebulizer attached to a cyclonic chamber was employed. 
The theoretical base of the chosen method is related to the formation of stibine $\left(\mathrm{SbH}_{3}\right)$ from $\mathrm{Sb}(\mathrm{III})$ and $\mathrm{NaBH}_{4}$ reaction in acid. The volatile nature of $\mathrm{SbH}_{3}$ makes it easily transported to the plasma through argon. The citric acid is used to produce the selective complexation of $\mathrm{Sb}(\mathrm{V})$, allowing the $\mathrm{Sb}(\mathrm{III})$ to remain free to form $\mathrm{SbH}_{3}$ in a selective manner. Helicoidal reactors, built with polyethylene tube, were used to control the contact time between the sample and the citric acid. This period is crucial to determine the complex formation.

The influence of citric acid concentration was evaluated in the formation of $\mathrm{SbH}_{3}$ through $\mathrm{Sb}(\mathrm{III})$ and $\mathrm{Sb}(\mathrm{V})$. Initially, we tested the citric acid solutions at 2, 4, 10, 15, 20, 25 and $30 \%$. The average emission intensity of the analysis in triplicate for each concentration was recorded to evaluate the influence of the citric acid concentrations in the proposed method. In addition $\mathrm{NaBH}_{4}$ solutions in concentrations of $1,2,3,4,5$ and $6 \%$ were prepared to evaluate its influence in the measured emission intensities. For this purpose the citric acid concentration was maintained at $30 \%$.

The reactors made with polyethylene tubes of 1,2 , 5 and $6 \mathrm{~m}$ were tested using citric acid solution 30\% and $\mathrm{NaBH}_{4} 2 \%$ in $\mathrm{NaOH} 0.01 \mathrm{~mol} / \mathrm{l}$, with the purpose of evaluating the influence of contact time between the sample and the citric acid solution in the intensity of the emissions. The operational parameters of the method are listed in Table I.

The following inorganic standards were used in these test: $\mathrm{Sb}$ (III) (Antimony Potassium Tartrate Trihydrate) in water $(0.5 \mathrm{mg} / \mathrm{l})$; $\mathrm{Sb}(\mathrm{V})$ (Antimony Potassium Hexammoniate), $20 \mathrm{mg} / \mathrm{l}$; a solution containing $\mathrm{Sb}$ (III) and $\mathrm{Sb}(\mathrm{V}), 0.5$ and $20 \mathrm{mg} / 1$ respectively. In the reactor length tests a commercial sample solution diluted 4,000 x was used in addition to the inorganic standards of $\mathrm{Sb}$ (III) 0.5 $\mathrm{mg} / \mathrm{l}$ and $\mathrm{Sb}(\mathrm{V}) 20 \mathrm{mg} / \mathrm{l}$. The analysis parameters were determined through the results obtained in the selectiveness test, and the method was thus validated.

To characterize the meglumine antimoniate, the quality of the raw material was evaluated according to the Brazilian Pharmacopeia (2002). Tests were conducted to verify the following characteristics: solubility; pres- ence of heavy metals (Al, As, Bi, Cd, Cr, Cu, Mn, Ni, $\mathrm{Pb}, \mathrm{Zn}, \mathrm{Hg}$ ) through the ICP-OES technique with optical system of the sequential type, using the ASSORANCE Spex Certiprep reference standards; and the degree of oligomerization of the active, estimated by X-ray diffraction (XRD). $\mathrm{Sb}(\mathrm{III})$ and $\mathrm{Sb}(\mathrm{V})$ percentages in the raw material were determined by $\mathrm{HG}-\mathrm{AAS}$ and AAS techniques, respectively.

Data processing - The Microsoft Excel software was used to perform the statistical calculations. Statsoft software was used to build the Box Plot, used as an auxiliary tool in the evaluation of the formulations.

Method validation - The linearity was tested at a concentration range of 0.1 to $1.0 \mathrm{mg} / 1$ of five different concentrations $(0.1 ; 0.25 ; 0.5 ; 0.75$ and $1.0 \mathrm{mg} / \mathrm{l})$. The standard calibration curve was used for determining linearity. These standards were tested six times, following the rules of the International Conference on Harmonization (ICH 2005). A calibration curve was constructed and the proposed method was evaluated by its correlation coefficient and interception value, calculated in the corresponding statistic study (ANOVA) $(\mathrm{p}<0.05)$. Characteristic parameters for regression equation $(y=a+b x)$ of the analytical method, obtained by least squares treatment of the results, confirmed the good linearity of the developed method.

The assay accuracy was measured by analyzing three spiked samples (80, 100 and 120\%). According to the ICH (2005) recommendations, precision must be considered at two levels including repeatability and intermediate precision. Repeatability refers to the use of the analytical procedure within a laboratory over a short period of time using the same analyst with the same equipment. For this parameter, six replicated samples were consecutively tested using the same equipment at a concentration of $100 \%(0.8 \mathrm{mg} / \mathrm{ml})$ of the regular analytical working value. The intermediate precision expresses the variations within laboratories, and was assessed six times by using different equipment, analysts and days to analyze three samples (glucamine from Aventis Pharma Lab - Brazil).

TABLE I

Summary data of ICP and hydride generation - inductively coupled plasma atomic emission spectrometry (HG-ICP-AES) determination parameters

\begin{tabular}{lll}
\hline Potency $(\mathrm{w})$ & ICP (usual nebulizer) & HG-ICP-AES \\
\cline { 2 - 3 } & 1,200 & 1,200 \\
\hline Ar flow (1/min) & Nebulizer: 0.48 & Nebulizer: 0.22 \\
& Plasma: 15 & Plasma:15 \\
& Gas:0 & Gas:0 \\
Nebulizer - aspiration rate (1/min) & Sheath gas: 0.2 & - \\
& Meinhard & \\
Citric acid flow (ml/min) & Cyclonic chamber: 2.73 & 0.6 \\
Sodium borohydride flow (ml/min) & - & 1.7 \\
Sample flow (ml/min) & - & 1.3 \\
\hline
\end{tabular}


TABLE II

New produced formulations (F1-F8) for meglumine antimoniate

\begin{tabular}{lcccrrrrr}
\hline Ingredients (\%) & F1 & F2 & F3 & F4 & F5 & F6 & F7 & F8 \\
\hline Meglumine antimoniate & 29.78 & 29.78 & 29.78 & 29.78 & 29.78 & 29.78 & 29.78 & 29.78 \\
Sodium metabisulfite & 0.05 & 0.05 & 0.05 & 0.05 & 0.05 & 0.05 & 0.05 & 0.05 \\
EDTA.2Na & 0.10 & 0.10 & 0.10 & 0.10 & 0.10 & 0.10 & 0.10 & 0.10 \\
Methyl paraben & 0.10 & 0.10 & 0.10 & 0.10 & 0.10 & 0.10 & 0.10 & 0.10 \\
NaOH & - & 0.09 & - & 0.09 & - & 0.09 & - & 0.09 \\
KH PO4 & - & 1.05 & - & 1.05 & - & 1.05 & - & 1.06 \\
Propylene glycol & - & - & - & - & 14.0 & 13.83 & 34.83 & 34.4 \\
Water & 69.97 & 68.83 & 69.97 & 68.83 & 56.0 & 55.17 & 34.83 & 34.4 \\
\hline
\end{tabular}

The limit of quantification was obtained from the blank standard deviation of the calibration curves of the eight samples. It was determined according to the average of the blank value multiplied by ten and divided by the angular coefficient.

Formulations - To evaluate the improvement of the compound stability in terms of the formation of toxic sub products (i.e., $\mathrm{Sb}(\mathrm{III})$ derivate), and some physicalchemical properties, such as $\mathrm{pH}$, density and percentage of $\mathrm{Sb}(\mathrm{V})$, different formulations were prepared and monitored over a period of 30,60 and 90 days in a climatic chamber maintained at $50^{\circ} \mathrm{C}$, after initial analysis. The prepared formulations are listed on Table II.

\section{RESULTS AND DISCUSSION}

Speciation analysis strategy - Many parameters such as citric acid concentration, $\mathrm{NaBH}_{4}$ concentration and reactor size were evaluated to determine the method selectivity, that is, the determination of $\mathrm{Sb}$ (III) species in the presence of large quantities of $\mathrm{Sb}(\mathrm{V})$ species, without the latter one interfering in the analysis. $\mathrm{Sb}(\mathrm{V})$ may react with $\mathrm{NaBH} 4$, but have slower $\mathrm{HG}$ than the corresponding $\mathrm{Sb}$ (III), so then the signals are produced by the pentavalent species depending on HG conditions. Therefore it is feasible to monitor the same sample both directly and after quantitative reduction to the trivalent state based on the different sensitivity for HG-ICP-AES technique. Several methodologies have been used for $\mathrm{Sb}(\mathrm{V})$ and $\mathrm{Sb}$ (III) quantification in different matrices. However herein the HG-ICP-AES technique was used for the first time to evaluate a new pharmaceutical formulation quality presenting these species (Apte \& Howard 1986, Casiot et al. 1998, Cava-Montesinos et al. 2003, González et al. 2005, Morita et al. 2007).

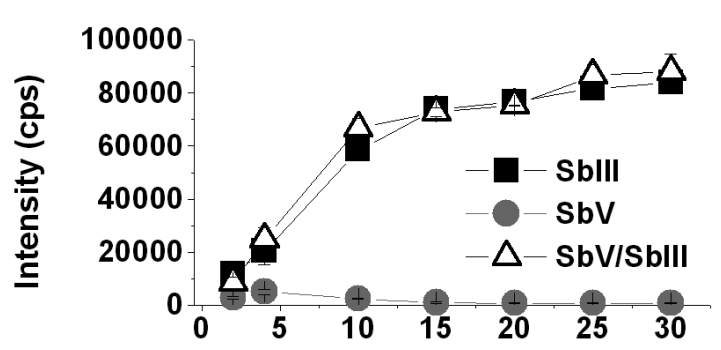

Fig. 1: citric acid concentration $(1.0-30.0 \% \mathrm{~m} / \mathrm{v})$ effect in hydride generation - inductively coupled plasma atomic emission spectrometry (HG-ICP-AES).
Citric acid concentration effect - The increase in the citric acid concentration led to an increase in the emission signal for the $\mathrm{Sb}(\mathrm{III})$, both for the $\mathrm{Sb}$ (III) solution as well as for the solution containing $\mathrm{Sb}(\mathrm{III})$ and $\mathrm{Sb}(\mathrm{V})$ (Fig. 1). This is probably due to the reduction in the solution $\mathrm{pH}$, which should contribute to increase the speed of reduction of $\mathrm{Sb}$ (III) by $\mathrm{NaBH}_{4}$. After the citric acid concentration reaches $20 \%$, it tends to stabilize. At this point, the solution $\mathrm{pH}$ is very low, and does not cause as much impact in the speed and selectivity of the reaction. It was previously observed that the complexation of $\mathrm{Sb}(\mathrm{V})$ with citric acid is improved in lower $\mathrm{pH}$ values (de la Calle Guntiñas et al. 1991). The study also demonstrated that the emission signal for the $\mathrm{Sb}(\mathrm{V})$ is suppressed with the increase in citric acid concentration (> 10\%), probably due to the complexation of $\mathrm{Sb}(\mathrm{V})$ with citric acid, reducing even further the reduction velocity of this species to $\mathrm{SbH}_{3}$.

Mohammad and co-workers had already reported the $\mathrm{pH}$ influence in the absorption signal increase, both for $\mathrm{Sb}(\mathrm{III})$ and for $\mathrm{Sb}(\mathrm{V})$, when they studied the $\mathrm{pH}$ influence in speciation of $\mathrm{Sb}(\mathrm{III})$ and $\mathrm{Sb}(\mathrm{V})$ using HG-AAS (Mohammad et al. 1990). The drop in intensity is not observed in the solution containing the two species, in which the signal increases due to the presence of $\mathrm{Sb}(\mathrm{III})$, as demonstrated in Fig. 1. The chosen concentration of citric acid for the remaining assays was $30 \%$, considering that at this level the maximum intensity values were observed both for $\mathrm{Sb}(\mathrm{III})$ and for the mixture of both, with the $\mathrm{Sb}(\mathrm{V})$ intensity remaining unchanged.

To verify the intensities of $\mathrm{Sb}$ (III) in different citric acid concentrations, we used the $t$-test of multiple comparison with Bonferroni correction. The Snedecor F test was performed to verify if the variances were comparable. The calculated $\mathrm{F}$ value (14.44) was smaller than the critical F (39.0) for all pairs and the intensities were comparable at 20,25 and $30 \%$ intensities but not at $15 \%$. Our results pointed $20 \%$ concentration as ideal to work in this concentration range without modifying the results.

Sodium borohydride concentration effect - The $\mathrm{NaBH}_{4}$ reductor was tested at 1, 2, 3, 4, 5 and $6 \%$ stabilized in a $\mathrm{NaOH} 0.01 \mathrm{M}$ solution. An increase in the concentration of $\mathrm{NaBH}_{4}$ increases significantly the emission signal of $\mathrm{Sb}(\mathrm{III})$, both in the $\mathrm{Sb}$ (III) solution and in the solution containing $\mathrm{Sb}(\mathrm{III})$ and $\mathrm{Sb}(\mathrm{V})$. Concentrations above $3 \%$ tend slightly to increase the $\mathrm{Sb}(\mathrm{V})$ signal, both in the $\mathrm{Sb}(\mathrm{V})$ solution and in the solution containing both 
species, $\mathrm{Sb}(\mathrm{III})$ and $\mathrm{Sb}(\mathrm{V})$, showing that in these concentrations the citric acid does not have the same power to reduce the formation of $\mathrm{SbH}_{3}$ from $\mathrm{Sb}(\mathrm{V})$.

Despite of using a different matrix, the results agree with those from Flores and co-workers about the evaluation of the influence of the reductor concentration in the formation of $\mathrm{SbH}_{3}$ using flow injection HG-AAS, except when the concentration exceeded $4 \%$ (Flores et al. 2002). These values may be compared to those determined in the analyses developed herein as they involve the use of the same solvent $\left(\mathrm{H}_{2} \mathrm{O}\right)$. In this way, the $\mathrm{NaBH}_{4}$ concentration of $2 \%$ was selected as the signal for $\mathrm{Sb}$ (III) since in this situation it is much higher than with lower concentrations, and the $\mathrm{Sb}(\mathrm{V})$ interference is meaningless, as shown in Fig. 2.

Helicoidal reactor length effect - The studies of reactor size used in the analysis were considered important as the reaction time between the sample and the citric acid interferes in the complexation yield. This may lead to a low reproducibility when working industrially as previously demonstrated and described in the Brazilian

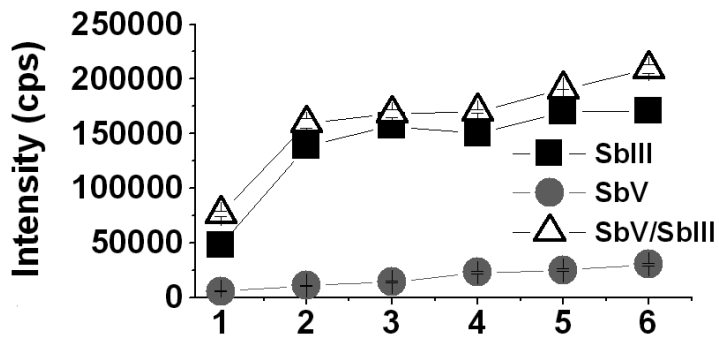

Fig. 2: $\mathrm{NaBH}_{4}$ concentration (1.0-6.0\% m/v) effectt in HG-ICP-HGICP-AES
Pharmacopeia (2002). The use of the different reactors $(0,1,2,5$ and $6 \mathrm{~m})$ did not show any conclusive results. The spectral resolution in ICP-OES showed a high resolution $(\sim 5.0 \mathrm{mg} / \mathrm{ml})$ in ideal conditions, which indicated no spectral interference in the chosen wavelength.

Method validation - Both methods presented correlation coefficients above 0.999 , and were thus considered linear in the studied concentration range. The achieved linear regression parameters for both methods are presented in Table III. The methods presented an average recovery rate (\%RR) of $101.31 \%$ for $\mathrm{Sb}(\mathrm{III})$ and $101.51 \%$ for $\mathrm{Sb}$ (total) in the three studied concentration levels. The relative standard deviation (RSD) of the replicates of each concentration level did not exceed 5\% (Table IV).

Through the student $t$-test, the hypothesis of significant difference in the three concentration levels was tested, and no evidence was found of a systematic error in the method. In addition, the calculated averages are statistically the same as the expected theoretical values. We also verified that the expected theoretical value is within the confidence interval of the obtained results. In the determination of the concentrations found in six replicates (Table V) for the Sb (III) analysis, a RSD of 3.53\% was observed, and for $\mathrm{Sb}(\mathrm{V})$ analysis, a RSD of $2.54 \%$. The results achieved in the analysis of the formulated product, with different days and analysts, are described in Table VI. The $t$-test application with grouped variances the Snedecor F test, was applied and showed that the variances between the results obtained in different days with different analysts were statistically identical. The $t$-test confirmed the method precision. The results obtained for the quantification limit of both methods are described in Table VII, and are compatible with the concentration levels observed in the analysis.

TABLE III

Method recovery

\begin{tabular}{|c|c|c|c|c|c|c|c|c|c|c|}
\hline \multirow[b]{2}{*}{ Level (\%) } & \multicolumn{5}{|c|}{$\mathrm{Sb}(\mathrm{III})$} & \multicolumn{5}{|c|}{$\mathrm{Sb}$ total } \\
\hline & $\begin{array}{l}\text { Spiked } \\
\text { amount } \\
(\mathrm{mg} / \mathrm{ml})\end{array}$ & $\begin{array}{l}\text { Spiked } \\
\text { found } \\
(\mathrm{mg} / \mathrm{ml})\end{array}$ & RSD (\%) & RF (\%) & IC & $\begin{array}{l}\text { Spiked } \\
\text { amount } \\
(\mathrm{mg} / \mathrm{ml})\end{array}$ & $\begin{array}{l}\text { Concentration } \\
(\mathrm{mg} / \mathrm{ml})\end{array}$ & RSD (\%) & RF (\%) & IC \\
\hline 80 & 3,203 & 3,201 & 3.73 & 99.9 & 0.296 & 66.25 & 67.20 & 0.977 & 101.43 & 0.743 \\
\hline 100 & 4,000 & 4,087 & 3.15 & 102.2 & 0.146 & 81.00 & 82.17 & 1,652 & 101.45 & 1,536 \\
\hline 120 & 4,799 & 4,887 & 4.6 & 101.8 & 0.254 & 97.20 & 98.80 & 2,562 & 101.65 & 2,865 \\
\hline
\end{tabular}

TABLE IV

Method precision

\begin{tabular}{|c|c|c|c|c|c|c|c|c|c|}
\hline \multirow[b]{2}{*}{$\begin{array}{l}\text { Concentration } \\
(\mathrm{mg} / \mathrm{ml})\end{array}$} & \multicolumn{4}{|c|}{$\mathrm{Sb}(\mathrm{III})$} & \multicolumn{5}{|c|}{ Total Sb } \\
\hline & $\begin{array}{l}\text { Media } \\
(\mathrm{mg} / \mathrm{ml})\end{array}$ & SD & RSD (\%) & $\mathrm{S}^{2}$ & $\begin{array}{l}\text { Concentration } \\
(\mathrm{mg} / \mathrm{ml})\end{array}$ & $\begin{array}{l}\text { Media } \\
(\mathrm{mg} / \mathrm{ml})\end{array}$ & SD & RSD (\%) & $\mathrm{S}^{2}$ \\
\hline 0.4300 & & & & & 72.904 & & & & \\
\hline 0.4376 & & & & & 70.612 & & & & \\
\hline 0.4565 & 0.4045 & 0.016 & 3.53 & 0.000242 & 72.414 & 70.53 & 1.79 & 2.54 & 3.21 \\
\hline 0.4260 & & & & & 69.626 & & & & \\
\hline 0.4296 & & & & & 68.972 & & & & \\
\hline 0.4630 & & & & & 68.628 & & & & \\
\hline
\end{tabular}


TABLE V

Quantification limits for antimony analysis

\begin{tabular}{lccccc}
\hline $\begin{array}{l}\text { Sample } \\
\text { (Sb III) }\end{array}$ & $\begin{array}{c}\text { Conc. } \\
(\mathrm{mg} / \mathrm{ml})\end{array}$ & Media & SD & Slope & QL (mg/l) \\
\hline blank 1 & 0.0023 & & & & \\
blank 2 & 0.0019 & 0.00175 & 0.0004209 & 535277 & 0.0000217 \\
blank 3 & 0.0023 & & & & \\
blank 4 & 0.0017 & & & & \\
blank 5 & 0.0011 & & & & \\
blank 6 & 0.0014 & & & & \\
blank 7 & 0.0015 & & & & \\
blank 8 & 0.0018 & & & & \\
\hline Sample & Conc. & & & & \\
(Sb total) & $(\mathrm{mg} / \mathrm{ml})$ & Media & SD & Slope & QL (mg/l) \\
\hline blank 1 & 0.0026 & & & & \\
blank 2 & 0.0045 & 0.0029 & 0.00138 & 44,306 & 0.000071 \\
blank 3 & 0.0043 & & & & \\
blank 4 & 0.0014 & & & & \\
blank 5 & 0.0044 & & & & \\
blank 6 & 0.0016 & & & & \\
blank 7 & 0.0031 & & & & \\
blank 8 & 0.0013 & & & & \\
\hline
\end{tabular}

Development of meglumine antimoniate formulation - Active pharmaceutical ingredients of three different origins were tested to select the one presenting the ideal characteristics for the methyl meglumine injectable formulations. The chosen compound (Aventis Pharma) showed good solubility and no agglomeration profile in XRD, which supports the proposal of an undefined and oligomeric chemical structure. The particles were amorphous and with undefined geometry. The size distribution was measured with medium diameter of 15 to $20 \mu \mathrm{m}$. The total concentration of the analyzed heavy metals was $3.7121 \mathrm{mg} / \mathrm{l}$, a value below the maximum specified level $(10 \mathrm{mg} / \mathrm{l})$. The obtained percentages of $\mathrm{Sb}$ (III) and $\mathrm{Sb}$ (total) were $0.49 \pm 0.0 \%$ and $27.7 \pm 0.3 \%$, respectively. The calculated percentage of $\mathrm{Sb}(\mathrm{V})$ was $27.2 \pm 0.3 \%$, indicating the suitability of the synthetic process and confirming the choice of the compound cited above, even though its acquisition cost is higher.

During stability studies, the results of the $\mathrm{pH}$ and density values evaluation for new formulations are described in Table VI. The values of Student $t$-test for multiple comparisons, using Bonferroni correction, showed there were no significant variations for all pairs of the 1, 2, 3, 4, 5 and 6 formulations during the 90 days. However, differ-

TABLE VI

New meglumine antimoniate formulations evaluation

\begin{tabular}{|c|c|c|c|c|c|c|c|c|c|}
\hline Parameter & Days & $\mathrm{F} 1$ & $\mathrm{~F} 2$ & F3 & $\mathrm{F} 4$ & F5 & F6 & F7 & F8 \\
\hline \multirow[t]{4}{*}{$\mathrm{pH}$} & 0 & $\begin{array}{l}6.14 \pm \\
0.0495\end{array}$ & $\begin{array}{l}6.44 \pm \\
0.0071\end{array}$ & $\begin{array}{l}6.12 \pm \\
0.0141\end{array}$ & $\begin{array}{l}6.44 \pm \\
0.0141\end{array}$ & $\begin{array}{l}5.95 \pm \\
0.0141\end{array}$ & $\begin{array}{l}6.44 \pm \\
0.1202\end{array}$ & $\begin{array}{l}6.72 \pm \\
0.0141\end{array}$ & $\begin{array}{c}6.72 \pm \\
0.0283\end{array}$ \\
\hline & 30 & $\begin{array}{l}5.86 \pm \\
0.0141\end{array}$ & $\begin{array}{l}6.57 \pm \\
0.0141\end{array}$ & $\begin{array}{l}6.23 \pm \\
0.0495\end{array}$ & $\begin{array}{l}6.54 \pm \\
0.0141\end{array}$ & $\begin{array}{l}5.81 \pm \\
0.0424\end{array}$ & $\begin{array}{l}6.29 \pm \\
0.2333\end{array}$ & $\begin{array}{l}5.97 \pm \\
0.0566\end{array}$ & $\begin{array}{c}6.36 \pm \\
0.0778\end{array}$ \\
\hline & 60 & $\begin{array}{l}5.75 \pm \\
0.1556\end{array}$ & $\begin{array}{l}6.58 \pm \\
0.0282\end{array}$ & $\begin{array}{l}6.25 \pm \\
0.0354\end{array}$ & $\begin{array}{c}6.525 \pm \\
0.0495\end{array}$ & $\begin{array}{l}5.76 \pm \\
0.0566\end{array}$ & $\begin{array}{l}6.39 \pm \\
0.0566\end{array}$ & $\begin{array}{l}6.04 \pm \\
0.1343\end{array}$ & $\begin{array}{c}6.32 \pm \\
0.0071\end{array}$ \\
\hline & 90 & $\begin{array}{l}5.69 \pm \\
0.0283\end{array}$ & $\begin{array}{l}6.54 \pm \\
0.0283\end{array}$ & $\begin{array}{l}6.54 \pm \\
0.0420\end{array}$ & $\begin{array}{l}6.23 \pm \\
0.0283\end{array}$ & $\begin{array}{l}5.77 \pm \\
0.0141\end{array}$ & $\begin{array}{l}6.03 \pm \\
0.4808\end{array}$ & $\begin{array}{l}5.90 \pm \\
0.0283\end{array}$ & $\begin{array}{l}6.37 \pm \\
0.0141\end{array}$ \\
\hline \multirow[t]{4}{*}{ density } & 0 & $\begin{array}{c}1.1639 \pm \\
0.0306\end{array}$ & $\begin{array}{c}1.1680 \pm \\
0.0304\end{array}$ & $\begin{array}{c}1.1628 \pm \\
0.0321\end{array}$ & $\begin{array}{c}1.1684 \pm \\
0.0287\end{array}$ & $\begin{array}{c}1.1710 \pm \\
0.0326\end{array}$ & $\begin{array}{c}1.1797 \pm \\
0.0337\end{array}$ & $\begin{array}{c}1.1834 \pm \\
0.0304\end{array}$ & $\begin{array}{l}1.1989 \pm \\
0.03605\end{array}$ \\
\hline & 30 & $\begin{array}{c}1.1640 \pm \\
0.0306\end{array}$ & $\begin{array}{c}1.1684 \pm \\
0.0296\end{array}$ & $\begin{array}{c}1.1633 \pm \\
0.0316\end{array}$ & $\begin{array}{c}1.1722 \pm \\
0.0319\end{array}$ & $\begin{array}{c}1.1715 \pm \\
0.0319\end{array}$ & $\begin{array}{c}1.1840 \pm \\
0.0254\end{array}$ & $\begin{array}{c}1.1917 \pm \\
0.0315\end{array}$ & $\begin{array}{l}1.1962 \pm \\
0.02968\end{array}$ \\
\hline & 60 & $\begin{array}{c}1.1646 \pm \\
0.0314\end{array}$ & $\begin{array}{c}1.1697 \pm \\
0.0301\end{array}$ & $\begin{array}{c}1.1624 \pm \\
0.0316\end{array}$ & $\begin{array}{c}1.1737 \pm \\
0.0305\end{array}$ & $\begin{array}{c}1.1694 \pm \\
0.0288\end{array}$ & $\begin{array}{c}1.1801 \pm \\
0.0300\end{array}$ & $\begin{array}{c}1.1889 \pm \\
0.0302\end{array}$ & $\begin{array}{c}1.1919 \pm \\
0.0364\end{array}$ \\
\hline & 90 & $\begin{array}{c}1.1643 \pm \\
0.0306\end{array}$ & $\begin{array}{c}1.1704 \pm \\
0.0312\end{array}$ & $\begin{array}{c}1.1729 \pm \\
0.0328\end{array}$ & $\begin{array}{c}1.1652 \pm \\
0.0306\end{array}$ & $\begin{array}{c}1.1795 \pm \\
0.0419\end{array}$ & $\begin{array}{c}1.1776 \pm \\
0.0376\end{array}$ & $\begin{array}{c}1.1920 \pm \\
0.0316\end{array}$ & $\begin{array}{r}1.1990 \pm \\
0.03120\end{array}$ \\
\hline
\end{tabular}

\section{TABLE VII}

Sb total and $\mathrm{Sb}(\mathrm{III})$ amounts found meglumine antimoniate formulations in stability studies

\begin{tabular}{lcccccccc}
\hline & \multicolumn{2}{c}{ Initial } & \multicolumn{2}{c}{30 Days } & \multicolumn{2}{c}{60 Days } & \multicolumn{2}{c}{90 Days } \\
\cline { 2 - 9 } Formulation & $\begin{array}{c}\text { Sb total } \\
(\mathrm{mg} / \mathrm{ml})\end{array}$ & $\begin{array}{l}\mathrm{Sb}(\mathrm{III}) \\
(\mathrm{mg} / \mathrm{ml})\end{array}$ & $\begin{array}{c}\text { Sb total } \\
(\mathrm{mg} / \mathrm{ml})\end{array}$ & $\begin{array}{c}\mathrm{Sb}(\mathrm{III}) \\
(\mathrm{mg} / \mathrm{ml})\end{array}$ & $\begin{array}{c}\text { Sb total } \\
(\mathrm{mg} / \mathrm{ml})\end{array}$ & $\begin{array}{c}\mathrm{Sb}(\mathrm{III}) \\
(\mathrm{mg} / \mathrm{ml})\end{array}$ & $\begin{array}{c}\text { Sb total } \\
(\mathrm{mg} / \mathrm{ml})\end{array}$ & $\begin{array}{c}\text { Sb (III) } \\
(\mathrm{mg} / \mathrm{ml})\end{array}$ \\
\hline 1 & $75.7 \pm 1.2$ & $2.27 \pm 0.18$ & $76.62 \pm 0.95$ & $3.22 \pm 0.26$ & $77.04 \pm 0.70$ & $2.53 \pm 0.19$ & $76.78 \pm 0.64$ & $1.58 \pm 0.10$ \\
2 & $75.2 \pm 2.3$ & $2.33 \pm 0.34$ & $76.22 \pm 0.27$ & $3.46 \pm 0.08$ & $77.13 \pm 0.16$ & $1.19 \pm 0.04$ & $72.78 \pm 0.95$ & $1.26 \pm 0.14$ \\
3 & $77.7 \pm 1.1$ & $2.98 \pm 0.30$ & $76.20 \pm 0.87$ & $3.48 \pm 0.14$ & $75.93 \pm 0.52$ & $1.83 \pm 0.11$ & $72.63 \pm 0.67$ & $2.03 \pm 0.09$ \\
4 & $77.4 \pm 0.6$ & $2.49 \pm 0.26$ & $77.70 \pm 0.37$ & $2.95 \pm 0.08$ & $76.60 \pm 0.63$ & $2.02 \pm 0.28$ & $76.28 \pm 1.55$ & $0.93 \pm 0.16$ \\
5 & $77.1 \pm 1.3$ & $1.57 \pm 0.16$ & $79.02 \pm 0.97$ & $2.26 \pm 0.11$ & $75.58 \pm 0.42$ & $1.03 \pm 0.16$ & $75.68 \pm 0.97$ & $1.09 \pm 0.09$ \\
6 & $77.9 \pm 1.2$ & $0.97 \pm 0.10$ & $80.15 \pm 1.07$ & $2.31 \pm 0.24$ & $77.05 \pm 0.41$ & $1.37 \pm 0.04$ & $75.40 \pm 1.22$ & $1.09 \pm 0.24$ \\
7 & $79.4 \pm 1.4$ & $1.28 \pm 0.25$ & $73.92 \pm 0.45$ & $1.80 \pm 0.11$ & $76.91 \pm 0.55$ & $0.89 \pm 0.08$ & $71.99 \pm 1.39$ & $0.93 \pm 0.16$ \\
8 & $78.9 \pm 0.6$ & $1.33 \pm 0.34$ & $79.62 \pm 0.65$ & $2.07 \pm 0.08$ & $76.89 \pm 0.86$ & $1.75 \pm 0.01$ & $77.23 \pm 1.09$ & $1.17 \pm 0.10$ \\
\hline
\end{tabular}


ences were detected for the 7 and 8 formulations, which use propylene glycol/water in a 50:50 proportion without condemn the product in pharmacopeial terms. Neither the products autoclaving, formulations 1 and 2, nor the use of propylene glycol/water 20:80 as vehicle provide significant $\mathrm{pH}$ variations, corroborating previous studies of Romero (1996).

In terms of the studied formulations density, all calculated $t$ values for all pairs of all formulations were smaller than the critical t, leading to the conclusion that there was no significant difference in the formulations during the 90 days at a temperature of $50^{\circ} \mathrm{C}$.

The variations in the percentages of $\mathrm{Sb}$ (III) and $\mathrm{Sb}$ (V) in the proposed formulations were studied and listed in Table VII. The experimental $t$ values were smaller than the values of the critical $t$ for all formulation pairs, showing that the variation of the averages is equivalent, therefore showing there is no interference of the buffer in the quantities of $\mathrm{Sb}$ (III) found in the formulations. In all formulations, was found a $\mathrm{Sb}$ (III) increase at 30 days study. After this period, the value tends to decrease, and this phenomenon is related to the equilibrium achieved in the reaction of hydrolysis of meglumine antimoniate. For the evaluation of the autoclaving influence in the variation of the results obtained for $\mathrm{Sb}$ (III) in the formulations, we compared the averages of $\mathrm{Sb}$ (III) determined for formulations 1-3 and 2-4 during 90 days. The experimental $t$ values for both compared pairs were smaller than the critical $t$, showing that autoclaving did not interfere in the behavior of the species during the 90 days at $50^{\circ} \mathrm{C}$, in the prepared formulations. Nevertheless, we verified that the formulations subjected to autoclaving acquired a strong yellow color, indicating potential alterations in the organic portion of the molecule, not appropriate for its industrial processing.

The $\mathrm{Sb}(\mathrm{III})$ percentage in all formulations whose vehicle was only water, soon after preparation, were above the expected range, which is probably due to the higher dielectric constant of this solvent. In the formulations whose vehicles were mixtures of propylene glycol/ water, the percentages of $\mathrm{Sb}(\mathrm{III})$ remained within the admitted maximum values. The propylene glycol used as a co-solvent reduced the dielectric constant of the medium, thus reducing redox-type reactions, which corroborates the stability of the formulation. At same time, with high dielectric constant solvents, had already suggested that the structure of the meglumine antimoniate would have a great tendency towards dehydration reactions at high temperatures, forming a structure similar to an acetal (Carrió et al. 2000). This supposed structure could break with the subsequent hydrolysis of the structure, releasing $\mathrm{Sb}(\mathrm{V})$ in the medium, which would be free to suffer reduction reactions to $\mathrm{Sb}(\mathrm{III})$, depending on the conditions of the vehicle. As previously described, the propylene glycol works as an anti-hydrolytic agent in pharmaceutical formulations, which would minimize the release of $\mathrm{Sb}(\mathrm{V})$ in the medium, and would consequently further stabilize the prepared formulations. This fact, added to the conservation action of propylene glycol, which reduces the microbiological contamination of the product, confirming the solvent choice. The comparison of the formulations performed through the Box Plot showed that the formulations whose vehicles contained propylene glycol presented smaller values for $\mathrm{Sb}$ (III) and smaller variation of these values during the studied period. In terms of variation of $\mathrm{Sb}(\mathrm{V})$ percentages, there were no modifications, which allows us to indicate formulations 5 and 6 as the most stable among those studied. It is also advisable to use preferentially the sterilizing filtration process for manufacturing the meglumine antimoniate injectables, while also using activated carbon filtering as a complementary measure, to avoid possible contamination by heavy metals and probable processes of decomposition of meglumine. Propylene glycol concentration above $14.0 \%$ (formulations 7 and 8) conducted a reduction in formulations stability, indicating a direct stability/ vehicle dielectric constant relationship (Table II).

In conclusion, the results achieved in the study of development and validation of the analytical method, used to determine percentage of $\mathrm{Sb}(\mathrm{III})$ and $\mathrm{Sb}(\mathrm{V})$ in injectable formulations of meglumine antimoniate without separation of species, showed that the HG-ICP-AES method in continuous flow system is a safe and efficient alternative to the quality evaluation routine of these products in quality control laboratories. The method was demonstrated to be faster, more precise and more resilient than batch techniques. In the work performed with high concentration of species, the smaller quantification limits were not relevant.

The studies on the development of injectable formulations of this compound confirmed the initial idea of increased stability through reduction in the vehicle dielectric constant. Formulations 7 and 8, which used propylene glycol/water as a vehicle, in a 50:50 proportion, presented a higher stability degree regarding the increase in $\mathrm{Sb}$ (III) percentage than the preparations in aqueous vehicle, but with the inconvenient of higher $\mathrm{pH}$ variation, without compromising the quality of the end product. Formulations 5 and 6, which used propylene glycol/ water in 20:80 proportion as vehicles, were the most appropriate. However, considering the fact that injectable solutions should have the smallest possible quantity of additives, in the results we verified that the buffer was not needed to stabilize the product. Thus, formulation 5 would be eligible to scale up in the future.

Since the feasibility of potential oxidation-reduction reactions in the meglumine antimoniate molecule, it becomes necessary to use product filtering in activated carbon columns before product packaging, which should be evaluated in its scale up.

\section{REFERENCES}

Andreae MO, Asmode JF, Foster P, Van't dack L 1981. Determination of antimony(III), antimony(V) and methylantimony species in natural waters by atomic absorption spectrometry with hydride generation. Anal Chem 53: 1766-1771.

Apte SC, Howard AG 1986. Determination of dissolved inorganic antimony(V) and antimony(III) species in natural waters by hydride generation atomic absorption spectrometry. J Anal At Spectrom 1: 221-225.

Balana-Fouce R, Reguerra RM, Cubria C, Ordonéz D 1998. The pharmacology of leishmaniasis. Gen Pharmacol 30: 435-443. 
Barra CM, Santelli RE, Abrão JJ, de la Guardia M 2000. Arsenic speciation - A review. Quim Nova 23: 58-70.

Berman JD, Wyler DJ 1980. An in vitro model for investigation of chemotherapeutic agents in leishmaniasis. J Infect Dis 142: 83-86.

Bloomfield MS, Dow DA, Preble KA 1992. The determination of pentavalent antimony in sodium stibogluconate in a pharmaceutical formulation by flow-injection analysis. J Pharm Biomed Anal 10: 779-783.

Brazilian Pharmacopeia 2002. Brazilian Pharmacopeia Convention, 4nd ed., Atheneu, São Paulo, Fascicle 5, 268 pp.

Callahan HL, Portal AC, Devereux R, Grogl M 1997. An axenic amastigote system for drug screening. Antimicrob Agents Chemother 41: $818-822$.

Carrió J, Colmenares M, Riera C, Gállego M, Arboix M, Portús M 2000. Leishmania infantum: Stage- specific Activity of pentavalent Antimony related with the assay conditions. Exp Parasitol 95: 209-214.

Casiot C, Alonso MCB, Donard OFX, Potin-Gautier M, Alonso CB, Boisson J 1998. Simultaneous speciation of arsenic, selenium, antimony and tellurium species in waters and soil extracts by capillary electrophoresis and UV detection. Analyst 123: 2887-2893.

Cava-Montesinos P, de la Guardia A, Teutsch C, Cervera ML, de la Guardia M 2003. Non-chromatographic speciation analysis of arsenic and antimony in milk hydride generation atomic fluorescence spectrometry. Anal Chim Acta 493: 195-203.

Croft SL 1988. Recent developments in the chemotherapy of leishmaniasis. Trends Pharmacol Sci 9: 376-381.

de la Calle Guntiñas MB, Madrid Y, Cámara C 1991. Flow-injection and continuous-flow systems to determine antimony(III) and antimony $(\mathrm{V})$ by hydride generation atomic absorption spectrometry. Anal Chim Acta 252: 161-166.

Ephros M, Waldman E, Zilberstein D 1997. Pentostam induces resistance to antimony and the preservative chlorocresol in Leishmania donovani promastigotes and axenically grown amastigotes. Antimicrob Agents Chemother 41: 1064-1068.

Feng YL, Narasaki H, Chen HY, Tian LC 1999. Speciation of antimony (III) and antimony (V) using hydride generation inductively coupled plasma atomic emission spectrometry combined with the rate of pre-reduction of antimony. Anal Chim Acta 386: 297-304.

Flores EM, Paula FR, Silva FEB, Moraes DP, Paniz JNG, Santos EP, Dressler VL, Bittencourt VL 2003. Selective Determination of $\mathrm{Sb}(\mathrm{III})$ in Drugs by Flow Injection Hydride Generation AAS. At Spectr 24: 15-21.

Flores EM, Pereira ES, Barin JS, Zanella R, Dressler R, Bittencourt VL 2002. Determination of antimony (III) and total antimony by hydride generation atomic absorption spectrometry in samples of injectable drugs used for leishmaniasis treatment. $J$ Anal At Spectrom 17: 819-823.

González MJG, Renedo OD, Martínez MJA 2005. Simultaneous determination of antimony(III) and antimony(V) by UV-vis spectroscopy and partial least squares method (PLS). Talanta 68: 67-71.

ICH- International Conference on Harmonization 2005. Validation of Analytical Procedures: Text and Methodology; Q2(R1). Available from: http://www.ich.org/LOB/media/MEDIA417.pdf.

Lindemann T, Prange A, Dannecker W, Neidhart B 1999. Simultaneous determination of arsenic, selenium and antimony species using HPLC/ICP-MS. Fresenius J Anal Chem 364: 462-466.

Lintschinger J, Koch I, Serves S, Feldmann J, Cullen WR 1997. Determination of antimony species with high-performance liquid chromatography using element specific detection. Fresenius $J$ Anal Chem 359: 484-491.

Lintschinger J, Michalke B, Schulte-Hostede S, Schramel P 1998.
Studies on speciation of antimony in soil contaminated by industrial activity. Int $J$ Environ Anal Chem 72: 11-25.

Marsden PD 1979. Current concepts in parasitology. Leishmaniasis. N Engl J Med 300: 350-352.

Michalke B, Schramel P 1999. Antimony speciation in environmental samples by interfacing capillary electrophoresis online to an inductively coupled plasma mass spectrometer. $J$ Chromatogr 834: 341-348.

Mohammad B, Ure AM, Reglinski J, Littlejohn D 1990. Speciation of antimony in natural waters: The determination of $\mathrm{Sb}(\mathrm{III})$ and $\mathrm{Sb}(\mathrm{V})$ by continuous flow hydride generation-atomic absortion spectrometry. Chem Spec Bioavail 3: 117-122.

Morita Y, Kobayashi T, Kuroiwa T, Narukawa T 2007. Study on simultaneous speciation of arsenic and antimony by HPLC-ICPMS. Talanta 73: 81-86.

Pintado V, Lopez-Velez R 2001. HIV-associated visceral leishmaniasis. Clin Microbiol Infect 7: 291-300.

Rath S, Jardim WF, Dorea JG 1997. A simple spectrophotometric procedure for the etermination of antimony (III) and (V) in antileishmanial drugs. Fresenius J Anal Chem 358: 548-550.

Roberts WL, McMurray WJ, Rainey PM 1998. Characterization of the antimonial antileishmanial agent meglumine antimoniate (Glucantime). Antimicrob Agents Chemother 42: 1076-1082.

Romero GAS., Oliveira MRF., Correia D, Marsden PD. 1996. Características físico-químicas do antimoniato de meglumina em diferentes condições de armazenamento. Rev Soc Bras Med Trop 29: 461-465.

Smichowski P, Madrid Y, de la Calle Guntinas MB, Camara C 1995. Separation and determination of antimony(III) and antimony(V) species by high-performance liquid chromatography with hydride generation atomic absorption spectrometric and inductively coupled plasma mass spectrometric detection. J Anal At Spectrom 10: 815-821.

Sundar S, Sinha PR, Agrawal NK, Srivastava R, Rainey PM, Berman JD, Murray HW, Singh VP 1998. A cluster of cases of severe cardiotoxicity among kala-azar patients treated with a high-osmolarity lot of sodium antimony gluconate. Am J Trop Med Hyg 59: 139-143.

Trivelin LA, Rohwedder JJR, Rath S 2006. Determination of pentavalent antimony in antilheishmaniotic drugs using an automated system for liquid-liquid extraction with on-line detection. Talanta 68: 1536-1543.

Ulrich N 1998a. Speciation of antimony(III), antimony(V) and trimethylstiboxide by ion chromatography with inductively coupled plasma atomic emission spectrometric and mass spectrometric detection. Anal Chim Acta 359: 245-253.

Ulrich N 1998b. Study of ion chromatographic behavior of inorganic and organic antimony species by using inductively coupled plasma mass spectrometric (ICP-MS) detection. Fresenius $J$ Anal Chem 360: 797-800.

WHO- World Health Organization 2007. Leishmaniasis: disease information. Available from: http://www.who.int/tdr/diseases/ leish/diseaseinfo.htm.

Zhang X, Cornelis R, Mees L 1998. Speciation of antimony(III) and antimony $(\mathrm{V})$ species by using high-performance liquid chromatography coupled to hydride generation atomic absorption spectrometry. J Anal At Spectrom 13: 205-207.

Zheng J, Iijima A, Furuta N 2001. Complexation effect of antimony compounds with citric acid and its application to the speciation of antimony(III) and antimony(V) using HPLC-ICP-MS. $J$ Anal At Spectrom 16: 812-818.

Zheng J, Ohata M, Furuta N 2000. Studies on the speciation of inorganic and organic antimony compounds in airborne particulate matter by HPLC-ICP-MS. Analyst 125: 1025-1028. 